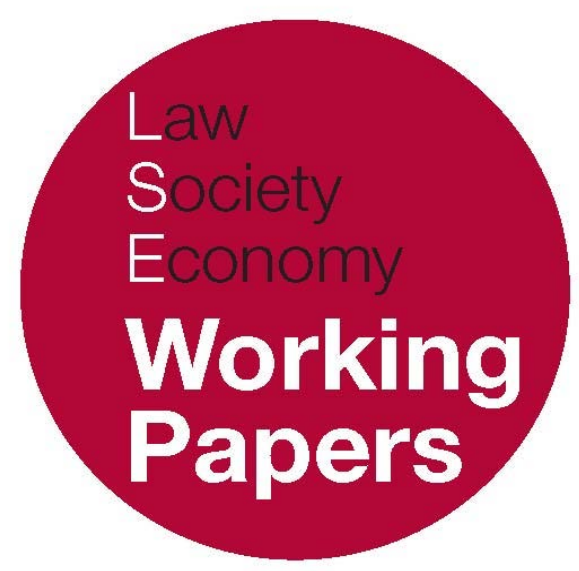

\title{
Volcker Rule, Ring-Fencing or Separation of Bank Activities: \\ Comparison of Structural Reform Acts Around the World
}

\author{
Matthias Lehmann \\ LSE Law, Society and Economy Working Papers 25/2014 \\ London School of Economics and Political Science \\ Law Department
}

\begin{abstract}
This paper can be downloaded without charge from LSE Law, Society and Economy Working Papers at: www.lse.ac.uk/collections/law/wps/wps.htm and the Social Sciences Research Network electronic library at: http://ssrn.com/abstract $=2519935$.

(C) Matthias Lehmann. Users may download and/or print one copy to facilitate their private study or for non-commercial research. Users may not engage in further distribution of this material or use it for any profit-making activities or any other form of commercial gain.
\end{abstract}




\title{
Volcker Rule, Ring-Fencing or Separation of Bank Activities:
}

\section{Comparison of Structural Reform Acts Around the World}

\author{
Matthias Lehmann*
}

\begin{abstract}
One of the key issues in the on-going overhaul of the global financial system is the structural reform of banking systems. Legislatures in different states, e.g. the United States, France, Germany, and the United Kingdom, have all taken measures to protect individual depositors' assets against losses from risky bank activities. On 29 January 2014, the European Commission joined the transnational effort by publishing its own proposal on the subject. This contribution shows how the same economic goal is implemented through different approaches by legislatures across the globe. It also analyses how this legal diversity will affect the level playing field in the competition for banking services and the consistency of global financial regulation.
\end{abstract}

\footnotetext{
* Professor of Law; Director, Institute of Private International and Comparative Law, University of Bonn, Germany, Germany; Visiting Researcher, London School of Economics and Political Science (LSE). This paper was presented at LSE's LLM Specialist Seminar in Corporate, Commercial and Financial Law on 12 March 2014. I wish to thank the participants for their helpful comments, in particular Carsten GernerBeuerle, Edmund Schuster, Guiliano Castellano, and Maria Beatrice Gilesi. Thanks also to Harvey Asiedu-Akrofi and Armin Grimm for assisting me with linguistic corrections and the footnotes. Any mistakes are of course mine. The elaboration of this paper was supported by the German Research Council (Deutsche Forschungsgemeinschaft - DFG).
} 


\section{INTRODUCTION}

Of all reforms triggered by the financial crisis since 2009, the US Volcker Rule, the UK 'ring-fencing' of bank deposits, and similar measures taken to change the structure of respective banking systems are the most far-reaching. The basic aim of these acts is to shield depositors' assets from risky bank activities. If deposits and risky activities are kept separate, so the idea goes, it would not matter whether other parts of the bank become insolvent. They could be unwound without the risk of creating a bank run or other systemic crisis.

Bank reorganisation measures are of fundamental importance. They directly affect the very structure of credit institutions. Ultimately, they may lead to the creation of a new financial landscape. The future of banking depends on them. In order to understand their economic impact, it is important to pay close attention to their legal attributes. Details that appear, at first sight, to be of a merely technical nature often reflect underlying assumptions about the social values of various financial services, about 'right' and 'wrong' banking activities, and about the appropriate amount of risk-taking for an economy. An ever so small rule or exemption can potentially influence the competitiveness and stability of a state's banking system and thereby impact a whole economy.

This contribution will analyse the different ways in which banking reorganisation has been designed in jurisdictions around the globe. It will show that no single measure is identical to another. The divergences between them are quite astonishing, especially since they all serve one and the same goal: to make the financial system more resilient. In the first part, the economic background of banking separation will be explained more thoroughly. Next, various national laws will be examined to determine how they try to accomplish this task. The study focuses on legislation adopted in the US, the UK, France, and Germany, as well as a draft proposal from the EU. The juxtaposition of all these measures triggers some thoughts on the effectiveness of the regulatory scheme around the world, which will be expounded on in the final part.

\section{ECONOMIC BACKGROUND}

\section{The CASe For Structural Reform}

Banking reorganisation measures were triggered by the dilemma that states found themselves in during the financial crisis. In 2008 and the years thereafter, many of them were forced to decide between rescuing ailing banks by injecting capital, or to risk losing depositors' assets which could trigger a run on credit institutions. At the heart of this decision were the tremendous losses that banks had incurred 
when investing in complex derivatives and structured finance products, such as mortgage-backed securities (MBS).

Most of the time, governments felt coerced or even 'blackmailed' into bailing out their banks in order to avoid triggering or deepening a systemic crisis. They responsively injected capital in the form of equity, loans or guarantees. The result was a gigantic bill for taxpayers. To illustrate, total state aid used to prop up banks in the EU alone was in the order of 1,6 trillion Euros in $2011 .{ }^{1}$ In some countries like Switzerland and the US, treasuries at least earned some profit in the end. In most other States, the public at large was directly exposed to the losses incurred by their institutions' risky behaviour. This created the impression that losses had been socialised while the gains from these activities remained in private hands. In the eyes of many citizens, the bailouts were less about rescuing their bank deposits and more about protecting the interests of bank owners whom had failed to properly supervise bank management. This view helped to provoke worldwide anti-capitalist movements, of which 'Occupy' is the most visible example. In the future, measures for structural reform shall exclude the need for such support and qualm the emotions of the public.

Proponents of a new bank structure also highlight another point - the need to avoid moral hazard. ${ }^{2}$ In fact, bailout measures have created the false impression that the state will save its most important, or 'systemically relevant', institutions under any circumstance. Markets quickly perceived this attitude as being tantamount to providing these institutions with an implicit state guarantee, nicknamed 'too big to fail'. This, it is argued, would undermine the discipline normally imposed by other market participants. ${ }^{3}$ Hence, banks would have an incentive to adopt even riskier behaviour than before because the losses would be partially covered by a public safety net. Structural reform is designed to reduce this moral hazard by curtailing the implicit state guarantee. Adherents argue that banks would no longer be able to 'blackmail' the state into a bailout by pointing to the need for deposit protection.

In addition to curtailing implicit government guarantees and avoiding moral hazard, structural reform is thought to also have a number of other benefits. First, it is hoped that if banks can no longer trade in securities, they will focus instead on their 'core function' of providing capital to non-financial sectors of the economy. ${ }^{4}$ Second, it is expected that banking separation will reduce dealings with other credit institutions and therefore reduce inter-connectedness - one of the main causes of the financial crisis. ${ }^{5}$ Third, it is also highlighted that reorganisation

${ }^{1}$ See UK Independent Commission on Banking, Final Report, September 2011 (henceforth: Vickers Report), p. 3.

${ }^{2}$ See in particular Vickers Report, p. 81.

3 Vickers Report, p. 77.

${ }^{4}$ See High-level Expert Group on reforming the structure of the EU banking sector, Final Report,

2 October 2012, (henceforth: Liikanen Report), p. vi.

${ }^{5}$ Liikanen Report, p. vi; Vickers Report, p. 25 (citing the Interim Report). 
measures will make deposit banks simpler and more transparent, thus facilitating their supervision ${ }^{6}$ as well as their resolution. ${ }^{7}$

\section{Counter-Arguments}

Each of the points made in favour of bank structure reform can be contested. One may argue for instance that diversification into different types of activities increases the banks' stability rather than undermining it. Some of the transactions that, at first sight, may be considered 'risky' or 'speculative' in fact strengthen their resilience. An example is engagement in the derivatives market, which may serve to hedge the specific risks of an institution.

Moreover, one might fear that risky activities now prohibited for banks will be transferred to other parts of the market. The beneficiary may be the so-called shadow banking sector, consisting e.g. of hedge funds. These actors are much less regulated and supervised than banks. The macroeconomic dangers resulting from their actions may thus completely escape the radar of supervisory authorities.

To corroborate the case against structural reform, it is also pointed out that the source of the crisis was not a bank providing universal service, but a proper investment bank - Lehman Bros. ${ }^{8}$ Its activities were already segregated from individual depositors' assets. Nevertheless, the collapse of Lehman Bros. was able to trigger a global financial crisis. Should such an event occur again, the government in question could feel pressured to bail out the affected institution. ${ }^{9}$ Thus, 'blackmailing' may occur even in a world of reformed bank structures.

One may also question whether the additional benefits of bank structure reform that regulators hope for will ultimately materialise. Instead of extending more loans to the non-financial sector of the economy, a likely reaction from banks could be to simply shrink their balance sheets. There is also a probability that inter-connectedness between financial institutions will be replaced by a dependency on funds provided by the central bank as a lender of last resort. Moreover, separation into different entities does not necessarily make supervisors' lives easier but can, on the contrary, result in additional complexity.

The most important argument against reorganisation measures are their costs. ${ }^{10}$ Compliance with the very elaborate rules and the necessary transfer of assets and activities to other entities requires high investments from the private sector. Estimates for UK banks range from $£^{4}-7$ bn annually pre-tax. ${ }^{11}$ It is to be expected that these costs will ultimately have to be borne by the banks' clients.

\footnotetext{
${ }^{6}$ Liikanen Report, p. iv.

7 Vickers Report, p. 9.

8 See Anat Admati and Martin Hellwig, The Bankers` New Clothes (Princeton University Press 2013), p. 90.

${ }^{9}$ This is recognised by the Vickers Report, see its p. 46.

10 See also Vickers Report, p. 10.

11 Vickers Report, p. 141.
} 
One may also fear that as a result of structural reform measures, the variety of services that banks offer is likely to be reduced. Clients who wish for different banking services will have to use more than one bank. The days of 'one-stopshopping' at only one institution would be definitely over. Furthermore, it must be borne in mind that by engaging in securities and derivatives trading, banks have also furthered important public interests. They have provided liquidity to the financial markets and allowed other parties to hedge risks. In the future, a farmer who wants to secure its investments against the price fluctuations of his products or the impact of climate change may experience difficulties in finding a proper counterparty.

\section{STRIKING A BALANCE BETWEEN STABILITY AND RISK}

The various counter-arguments have failed to convince the reformers. Their views have prevailed in the political arena. Structural reform measures are now commonplace in countries that feature a highly sophisticated financial industry.

This may be partly attributed to politicians reacting to the wishes of their electorate. An indistinct feeling that 'something needs to be done' was omnipresent after the financial crisis. It is now true that an overwhelming number of other measures have been adopted to re-establish market discipline and to shield deposits from losses. Examples include requirements for higher capital buffers, caps on managers' variable remuneration, and forced increases for bankfinanced deposit insurance funds. Yet the view was that even this range of measures is insufficient. Taxpayers and their representatives want to terminate 'once and for all' a situation in which depositors' assets may be used as a safety net for speculative transactions. Structural reform is the answer to this wish. In the eyes of its adherents, it will be the ultimate piece of a new financial architecture for the $21^{\text {st }}$ century.

In light of the experience of the financial crisis, states may be forgiven for having strived to be on the safe side. In the end, however, it is important to realise that there is no such thing as a 'fool-proof bank account'. If depositors' assets shall be put to some use and protected against inflation, then they cannot be kept locked away in safes. Yet if they are handed out to a third party, then they may be lost. This is true even where the recipient is the real economy. There is thus always a trade-off to be made between return and risk of bank deposits. The more secure that bank deposits are kept, the less they will grow and can be put to economic use. The way in which jurisdictions have drafted their separation measures informs us about how they have struck this balance. 


\section{THE VOLCKER RULE IN THE UNITED STATES: PROHIBITING RISKY ACTIVITIES}

Banking reorganisation measures are anything but new. They find historical precedence in the US Glass-Steagall Act. ${ }^{12}$ This piece of legislation prohibited commercial banks with privileged deposit insurance coverage from engaging in securities activities, while simultaneously excluding investment banks from accepting deposits. It was introduced as part of the 'New Deal' in 1933 as a response to the Great Depression where banks suffered major losses through securities dealings. ${ }^{13}$ Glass-Steagall dictated the evolution of the US financial system for a period of over 65 years until its most important restrictions were lifted in 1999 by the Gramm-Leach-Bliley Act. ${ }^{14}$ In the eyes of some observers, this reform was one of the major factors that ultimately led to the financial crisis. ${ }^{15}$ In spite of their historical experience - or precisely because of it - the United States did not reintroduce structural measures to segregate banks into different entities after the financial crisis of 2009. Instead, they opted for a restriction of certain activities by banks. These restrictions are laid out in the so-called Volcker Rule, named after the main proponent of the reform, former Chairman of the Federal Reserve Paul Volcker. It is part of the Dodd-Frank Act that was adopted as a response to the financial crisis in 2010. ${ }^{16}$ Banks have been given time until 22 July 2014 to comply with the new measures. ${ }^{17}$ This period has now ended.

The Volcker Rule prohibits two types of activities. First, bank entities are not allowed to engage in proprietary trading. In very simplified terms, this means that they cannot buy or sell securities for their own account. Second, they may not acquire or retain an interest in hedge funds or private equity funds. In the opinion of Paul Volcker, these two types of activities are too risky and at the same time not essential for deposit taking institutions. ${ }^{18}$ Although he does not deny their social utility, he thinks that they can be better taken care of by other market actors. Moreover, he argues that insolvable conflicts of interest would follow if deposit

\footnotetext{
${ }^{12}$ The Glass-Steagall Act is made up of four sections of the Banking Act of 1933 (Pub. L. No. 66, 48 Stat. 162 (1933): $₫ 16, \$ 20, \$ 21$ and $\$ 32$.

13 On the history of the Glass-Steagall-Act, see Bruce W. Nichols, 'Legislative History of the GlassSteagall Act', in: The Glass-Steagall-Act: Banks and the Securities Business, 15, 32-34 (1984); Larry Neal \& Eugene N. White, 'The Glass-Steagall Act in Historical Perspective', 52 The Quarterly Review of Economics and Finance 104-113 (2012).

14 Publ.L 106-102, 113 Stat. 1338.

${ }^{15}$ See, e.g., National Commission on the Causes of the Financial and Economic Crisis in the United States, p. 52-56.

16 See sec. 619 Dodd-Frank Wall Street Reform and Consumer Protection Act, Publ. L. 111-203, 124 Stat. 1376.

17 The entry into force was originally planned for 21st July 2012, see 12 U.S.C. \1851(c)(B). It has however been postponed for two years, 12 C.F.R $\$ 225.181$. For background, see Federal Reserve, Conformance Period for Entities Engaged in Prohibited Proprietary Trading or Private Equity or Hedge Fund Activities, 76 Fed. Reg. 8,276 (14 February 2011).

18 Paul Volcker, 'How to Reform Our Financial System', New York Times, 31 January 2010, p. 11.
} 
institutions were to engage in these activities. ${ }^{19}$ As an example of such a conflict, one may imagine a bank's interest in recommending shares or bonds to its customers after having added them to its own investment portfolio.

In order for the Volcker Rule to attain these goals, it does not suffice to vest deposit taking and risky activities in different members of a banking group. Even the strongest Chinese walls cannot avoid conflicts of interest of the kind that the rule seeks to exclude. Therefore, the US has chosen a different path. They not only apply the prohibitions to individual banks, but to entire banking groups as well. On a technical level, this was achieved by inserting the Volcker Rule into the so-called Bank Holding Companies Act. ${ }^{20}$ The scope of the prohibition to be found therein extends not only to depository institutions, but also to their parent companies and subsidiaries. ${ }^{21}$

As a result, the US features an even higher level of segregation than any other country. Deposit management on the one side, and proprietary trading and hedge and private activity funds on the other, are now not only separated into different parts of one group, but belong to two completely different universes.

The harshness of the separation contrasts with the limited scope of the prohibition. The Volcker Rule does not restrict the exercise of any activities other than proprietary trading and investments in hedge and private equity funds. For example, it does not stop banks from investing in US treasury bonds, from underwriting securities or market making, from risk-mitigating hedging activities, from buying and selling securities on behalf of their customers, from investing in small businesses or for the public welfare, or from organising and offering private equity and hedge funds. ${ }^{22}$

By now, the particular way in which the US legislator has struck the balance between risk and return becomes clear. On the one hand, the most dangerous activities with the highest tail and systemic risks are completely banned from banking. On the other hand, depository institutions may continue to offer investment banking services. The universal banking model thus remains perfectly legal. The legislator has only strived to make it safer by excluding certain types of activities that seemed particularly dangerous and unnecessary for the intermediation function that banks fulfil in the economy. In other words, he has excluded only what he considers to be unnecessary and economically futile 'speculation', but not useful banking services to clients.

From a legal point of view, the challenge to the Volcker Rule lies in the description of the excluded activities. Congress found itself unable to provide a self-standing definition. It left the matter to be determined by the competent government entities. There are no less than five of them: the Office of the Comptroller of the Currency (OCC), the Board of Governors of the Federal Reserve System, the Federal Deposit Insurance Corporation (FDIC), the Securities

\footnotetext{
${ }^{19}$ Volcker, id.

20 Sec. 13 Bank Companies Holding Act $=12$ U.S.C. $\int 1851$

${ }^{21}$ See 12 U.S.C. $₫ 1851(\mathrm{~h})(1)$.

${ }^{22}$ See the permitted activities enumerated in 12 U.S.C. $\$ 1851(\mathrm{~d})(1)(\mathrm{A})-(\mathrm{G})$.
} 
and Exchange Commission (SEC), and the Commodity Futures Trading Commission (CFTC). The first four of these agencies have submitted a common rule on 10 December 2013,23 while the CFTC has published its own final rule on 31 January 2014. ${ }^{24}$

Problems with defining the excluded activities do not only arise from the technical nature of the question. They are also due to the particular workings of the Volcker Rule. As discussed, securities dealings by banking entities are not excluded as such. They are only prohibited to the extent that they constitute 'proprietary trading'. But what is 'proprietary trading'? The statute defines some key features, using notions it then has to define in turn. ${ }^{25}$ Ultimately, it requires determining whether the securities were acquired to realise 'short-term profits'. ${ }^{26}$ This is a subjective criterion and not some objective type of activity, such as underwriting. It is therefore anything but simple to know when the definition is fulfilled. For these reasons, the enforcement of the Volcker Rule may in the end prove to be very difficult and costly, and the rule is prone to circumvention.

\section{FRANCE AND GERMANY: SUBSIDIARISING RISKY ACTIVITIES}

In 2013, the French and the German legislators introduced sweeping structural reforms that aimed to reorganise their national banking sectors. ${ }^{27}$ The measures had been the subject of a previous political agreement between the two states and are therefore closely coordinated. ${ }^{28}$ Both are inspired by the so-called Liikanen report drafted by a High Level Group of Experts established by the EU Commission, and chaired by the governor of the Finnish Central Bank, Erkki Liikanen. ${ }^{29}$ The measures will apply as of 1 July 2015. ${ }^{30}$

Both France and Germany aim to limit proprietary trading and investments in hedge funds and other leveraged investment funds by deposit-taking institutions.

\footnotetext{
23 See OCC, the Board of Governors of the Federal Reserve System, FDIC, SEC, Prohibitions and Restrictions on Proprietary Trading and Certain Interests in, and Relationships With, Hedge Funds and Private Equity Funds, 79 Federal Register 5536, codified in the various sections of the Federal Register for the rules adopted by the different agencies, 12 CFR Part 44, Part 248, Part 351 and 17 CFR Part 255.

${ }^{24}$ CFTC, Prohibitions and Restrictions on Proprietary Trading and Certain Interests in, and Relationships With, Hedge Funds and Private Equity Funds, 79 Federal Register 5808, codified in 17 CFR Part 75.

25 See 12 U.S.C. $\int 1851$ (h)(4).

${ }^{26}$ See 12 U.S.C. $\$ 1851(\mathrm{~h})(4)$ and (6).

${ }^{27}$ France: Loi no. 2013-672 du 26 juillet 2013 de séparation et de régulation des activités bancaires, J.O. n ${ }^{\circ} 173$ du 27 juillet 2013, p. 12530. Germany: Gesetz zur Abschirmung von Risiken und zur Planung der Sanierung und Abwicklung von Kreditinstituten und Finanzgruppen v. 7.8.2013, BGBl. 2013 I p. 3090.

28 See German Federal Government, Press Release, 6.2.2013, available at http://www.bundesfinanzministerium.de/Content/DE/Pressemitteilungen/Finanzpolitik/2013/02/201 3-02-06-PM12.html (last visited 18.3.2014).

${ }^{29}$ Liikanen Report, supra note 4.

${ }^{30}$ France: Art. 4-II of the Loi no. 2013-672. Germany: \64s(2) Kreditwesengesetz - KWG (German Banking Act).
} 
But in contrast to the United States, they do not completely prohibit these activities. Rather, they provide their banks with the option to either stop these activities altogether, or to exercise them through a subsidiary. The subsidiary is subject to a number of specific rules. It must be a separate legal entity solely dedicated to the exercise of risky activities. It cannot accept deposits or offer payment services to retail clients. ${ }^{31}$ It has to comply with capital requirements on an individual basis. ${ }^{32}$ The idea behind all of these rules is that depositors' assets shall be insulated from any losses that may result from risky activities, while maintaining the banking groups' ability to conduct such profitable activities.

Another peculiar feature of the French and German measures is their limited scope. In contrast to the Volcker Rule, they only apply to systemically significant financial institutions, or sifis. A sifi is defined using different thresholds. ${ }^{33}$ The important point here is not the exact criteria but rather the fact that not all banks are covered. Structural reform thus only affects the biggest institutions.

Despite some differences in details, one may say that France and Germany have struck the balance by containing the risks resulting from proprietary trading and certain investments for bank deposits, but not entirely excluding their banks from pursuing this type of funding. This is why they have to resort to structural reform measures. Banking groups are split into a deposit-taking institution and a trading entity. It is important to note that the trading entity will have to be the subsidiary, and not the other way around. This trait of the French and German laws is informed by the importance of the deposit-taking institutions in the respective countries.

The legal challenge is to precisely describe the activities that deposit-taking institutions may not engage in as well as the relations between them and the subsidiary. It is here that the French and German measures differ the most. For instance, the French legislation forbids certain activities by the subsidiary altogether, namely high frequency trading and derivatives transactions with agricultural commodities as an underlying. ${ }^{34}$ No such prohibition exists in Germany. France allows, on the other hand, the deposit-taking institution to transact with hedge funds and other leveraged investment funds if sufficient security is provided. ${ }^{35}$ This is not allowed for German banks. Diverging provisions are also made to assure the independence of the subsidiary vis-à-vis the rest of the group. In France, the subsidiary must have a commercial name that is distinct

\footnotetext{
31 Art. 511-48-I Code monétaire et financier (French Financial Services Act); $₫ 25 f(6)$ Kreditwesengesetz - KWG (German Banking Act).

32 Art. 511-48-I Code monétaire et financier (French Financial Services Act); \25f(2) Kreditwesengesetz - KWG (German Banking Act).

33 In France, a decree will have to spell out the precise criteria, see Art. 511-47-I Code monétaire et financier (French Financial Services Act). In Germany, the threshold is either total assets in the amount of Euro $100 \mathrm{bn}$ or more, or total assets in the amount of Euro $90 \mathrm{bn}$ or ore provided that the trading volume in the last three years was at least $10 \%$ of the total assets: $₫ 3(2) 1$ Kreditwesengesetz - KWG (German Banking Act).

34 Art. 511-48-II Code monétaire et financier (French Financial Services Act).

35 Art. 511-47-I 2 para. 7 Code monétaire et financier (French Financial Services Act).
} 
from that of the parent company. ${ }^{36}$ This is done in order to limit any temptation that the deposit-taking entity might have to bail out its subsidiary in case of failure. It is also required that the directors of the parent and the subsidiary be different. ${ }^{37}$ No such requirements exist in Germany. Here, the focus is more on transactions between the subsidiary and the other group members. The German Act provides that the subsidiary must refinance itself independently from the parent company and that transactions with other group members are to be considered as being concluded with third parties. ${ }^{38}$ This effectively means that the restrictions on large exposures $^{39}$ apply to such transactions. French law does not provide such a rule.

These few examples demonstrate that despite their similar goals and methods, the French and the German legislations will not have the same results. One can therefore not characterise the two legislations as being uniform. It is more precise to speak of a similar Franco-German 'approach'. In fact, a bank incorporated in France may look very different from one incorporated in Germany.

\section{UNITED KINGDOM: RING-FENCING THE DEPOSITS}

Westminster has chosen a different route for reorganisation. Based on the report by the Independent Commission on Banking, chaired by Sir John Vickers, ${ }^{40}$ it has decided to focus not only on risky activities, but also on the deposits themselves. The relevant rules are contained in the Financial Services (Banking Reform) Act 2013, which received royal assent on 18 December 2013. The day of its entry into force will be determined by an order of the Treasury. ${ }^{41}$ The act will amend the Financial Markets and Services Act (FSMA) 2000 by introducing new provisions. ${ }^{42}$ Once these provisions are brought into force, they will prescribe that deposits can only be accepted by special entities called 'ring-fenced bodies'. ${ }^{43}$ The latter are prohibited from exercising a certain number of activities (so-called 'excluded activities'). The Act simply mentions dealing in investments as a principal. ${ }^{44} \mathrm{It}$ is however planned that it will extend the realm of excluded activities much further so that it eventually covers all international, wholesale and investment banking services. 45

\footnotetext{
${ }^{36}$ Art. 511-48-I para. 7 Code monétaire et financier (French Financial Services Act).

37 Art. 511-48-I para. 8 Code monétaire et financier (French Financial Services Act).

${ }^{38}$ \& $25 \mathrm{f}(3)$ Kreditwesengesetz - KWG (German Banking Act).

39 See Art. 387 ss. Capital Requirements Regulation - CRR (Regulation (EU) No 575/2013 of 26 June

2013 on prudential requirements for credit institutions and investment firms, OJEU L 176/1).

40 Vickers Report, supra note 1.

${ }^{41}$ Sec. 148(5) Financial Services (Banking Reform) Act 2013.

${ }^{42}$ See sec. 142A-142J FSMA.

${ }^{43}$ Sec. $142 \mathrm{~A}(1)$ and 142B(1), (2) FSMA.

${ }^{4}$ Sec. $142 \mathrm{D}(1)$, (2) FSMA.

${ }^{45}$ See HM Treasury, Banking reform: delivering stability and supporting the economy, June 2012, p. 18.
} 
In contrast to the Volcker Rule, British law does not prohibit ring-fenced bodies from being part of a group that engages in excluded activities. They must however be sufficiently independent from this group. This is where the ring-fence becomes important. It serves as a shield between the deposit-taking entity and the other groups. The legislator has outlined some of its features, which are to be complemented by secondary legislation. It is required that the ring-fenced body be able to make decisions independently from the other group members and that it not depend on resources provided by them. ${ }^{46}$ It also has to be able to carry out its own activities in the event that one of the other members becomes insolvent. ${ }^{47}$ Contracts made with other group members must be concluded at arms' length. ${ }^{48}$ Ring-fenced bodies may be subject to more stringent capital requirements than other banks; in particular, the regulator may ask them to issue debt in specified amount which will allow the absorbance of losses. ${ }^{49}$ Depositors will enjoy preferential treatment in cases of insolvency. ${ }^{50}$ In short, one can say that the ringfence is designed to immunize the body and its clients from the woes of the rest of the group.

The idea of ring-fencing is quite straight-forward. Rather than encircle 'risky activities', as French and German laws do, the fence is instead drawn around deposits, which are in some way considered 'sacrosanct'. After all, what is most important, and what needs to be protected, are clients' deposits. At the same time, the UK did not consider it sufficient to simply prohibit banks from engaging in activities otherwise prohibited under US law. It was estimated that risks also arise from other activities such as wholesale and investment banking. ${ }^{51}$ Furthermore, it was highlighted that the Volcker Rule does nothing to diminish the interconnectedness between financial institutions because banks are still allowed to engage with each other. ${ }^{52}$ Moreover, it was argued that segregation between deposit-taking institutions and other banks would reduce complexity and allow for easier supervision and resolution. ${ }^{53}$

The structural changes due to the UK measures will be tremendous. In effect, banking groups will be broken up into retail and wholesale/investment banking entities. This does not only affect big or 'systemically important' banks, but rather all deposit-taking institutions, save for the power of the Treasury to exempt the smallest of them. ${ }^{54}$ The ring-fenced bodies will be prohibited from having any

\footnotetext{
46 Sec. $142 \mathrm{H}(4)$ (b)(i) FSMA.

47 Sec. $142 \mathrm{H}(4)$ (c) FSMA.

48 Sec. $142 \mathrm{H}(5)$ (a) FSMA.

49 See sec. 142Y(1) FSMA. On the exercise of this power, see the Draft Banking Reform (Loss

Absorbency Requirements) Order.

50 Sec. 13 Financial Services (Banking Reform) Act 2013.

51 Vickers Report, p. 45 s.

52 Vickers Report, p. 46.

53 Vickers Report, p. 46.

54 The Act merely allows the Treasury to exempt certain banks if it is likely that this has no significant adverse effects on the financial system's function to provide core banking services, Sec. 142A(2)(b) and (3) FSMA. The Treasury plans to introduce a de minimis exception for banks holding bank deposits of equal or less than $f^{25}$ billion, see sec. 6(1)(a) Draft Financial Services and Markets Act 2000 (Ring-fenced Bodies and Core Activities) Order.
} 
exposure to the other entities. ${ }^{55}$ Effectively, this means that they may not hold shares in the latter. As a result, retail banks in the UK cannot sit at the head of a bank group. Rather, they will be relegated to the role of an appendix.

This structure is opposite to that achieved under the French or the German approach. It is deemed to better fit the particular circumstances of the UK. Large global institutions are dominant here, for which retail banking is only a side activity. These institutions are too big to be bailed out by the government. Their main business presents considerable risks that the taxpayer should not carry. At the same time, it has been noted that the UK retail market is not very competitive and definitely needs the involvement of more market participants. ${ }^{56}$ It is therefore understandable that the UK government wants to insulate retail banks while not prohibiting big bank groups from offering retail services.

As a result of the structural changes, depository institutions governed by UK law will be particularly safe. Risks for bank clients as well as for UK taxpayers are substantially reduced. But such safety comes at a cost. The depository institutions will be prohibited from engaging in the most lucrative of activities. They may use depositors' assets exclusively for 'boring' transactions that are very secure, but yield only low returns. It is not far-fetched to assume that the banks' interests in managing deposits will reduce and that the cost for the clients will rise.

On a technical level, it is noticeable that the Act only identifies the core determinants of the new regime. The Act is described as being 'enabling' by the government. ${ }^{57}$ Many features are left to the discretion of the Treasury and the regulators. For them, it will be quite easy to identify the protected bodies. It is also more or less straightforward to describe the excluded activities. The challenges lie in the regulatory circumscription of the ring-fence. It is here that the Treasury will have much work to do.

\section{EU: SPLITTING UP BANK HOLDING GROUPS INTO DIFFERENT ENTITIES}

The last addition to the global panorama of structural reform measures emerges from the EU. 58 The comparatively late intervention by the Union should not be mistaken as a sign of a disinterest in the subject. After all, it was Commissioner Barnier who established the High Level Group of Experts that prepared the

\footnotetext{
55 HM Treasury, Banking reform: draft secondary legislation, July 2013, p. 18, and Draft Financial Services and Markets Act 2000 (Excluded Activities and Prohibitions) Order, sec. 1(3) 'financial institution exposure' and sec. 8(1).

56 Vickers Report, p. 165 ss.

${ }^{57}$ HM Treasury, Banking reform: delivering stability and supporting the economy, June 2012, p. 12.

58 European Commission, Proposal for a Regulation of the European Parliament and of the Council on structural measures improving the resilience of EU credit institutions, COM(2014), 43 final.
} 
'Liikanen Report'. The Commission has long mulled over what to make of the report. On 29 January 2014, it finally submitted a draft regulation. ${ }^{59}$

At the proposal's core is the prohibition of deposit institutions to engage in proprietary trading and to invest in alternative investment funds (AIF). ${ }^{60}$ The scope of the prohibition is restricted to systemically important institutions. ${ }^{61}$ Yet it not only applies to deposit-taking banks, but also to their parent companies and subsidiaries. ${ }^{62}$ Therefore, this activity cannot be outsourced. It is completely banned from the banking group. In this sense, the proposal resembles the Volcker Rule, and is stricter than the French and German Acts. At the same time, however, the prohibition is accompanied by some important exceptions. Proprietary trading in sovereign bonds, for instance, is permitted. ${ }^{63}$ This will ensure that private banks continue to finance Member States' governments. Yet from the viewpoint of financial stability, such an exception is hard to justify.

Another essential feature of the EU proposal, which distinguishes it from the Volcker Rule, is that it may lead to a mandatory separation of banking groups. Market-making, securitisations, complex derivatives transactions, and all other trading activities - unless exempted - may have to be transferred to a subsidiary. ${ }^{64}$ This part resembles both the French and the German legislations. In contrast to the latter, however, subsidiarisation does not take place automatically. Rather, it is left to the supervising authority to decide whether a separate entity will have to be established or not. Therefore, structural reform is not automatic, but merely optional.

A further particularity concerns the status of the trading entity. The proposal requires that it must be 'legally, economically and operationally separate' from the deposit-taking institution. ${ }^{65}$ In addition, the trading entity is prohibited from holding any capital instruments or voting rights in the latter. ${ }^{66}$ In contrast to the French and the German statutes, the trading entity can therefore not be a subsidiary of the deposit taking-institution. Rather, two distinct sub-groups must be created within the banking group: one for core banking activities and one for trading. ${ }^{67}$

Around the trading entity, a ring-fence is drawn that is reminiscent of the UK law. For instance, the parent is required to ensure that the trading entity's insolvency will not affect the deposit bank. ${ }^{68}$ Intra-group exposure of the latter

\footnotetext{
59 European Commission, Proposal for a Regulation of the European Parliament and of the Council on structural measures improving the resilience of EU credit institutions, $\mathrm{COM}(2014), 43$ final.

${ }^{60}$ Art. 6(1)(a), (b)(i), (ii) $\operatorname{COM}(2014), 43$ final.

${ }^{61}$ The EU proposal adopts a threshold of Euro 30 bn of total assets combined with the condition that the trading activities amounts to $10 \%$ of the assets (or Euro 70 bn), see Art. 3(1)(b) COM(2014), 43 final.

62 Art. 3(1)(a) $\operatorname{COM}(2014), 43$ final

63 Art. 6(2) COM(2014), 43 final.

${ }^{64}$ Art. 9, $13 \operatorname{COM}(2014), 43$ final.

65 Art. 13(1) COM(2014), 43 final.

66 Art. 13(5) COM(2014), 43 final.

67 See Art. 13(3) COM(2014), 43 final.

68 Art. 13(4) COM(2014), 43 final.
} 
must be limited, ${ }^{69}$ and contracts with other group members shall be made at arms' length. ${ }^{70}$ It is furthermore required that the two entities' management structures be kept independent of each other ${ }^{71}$ and that their names be distinguishable. ${ }^{72}$

As can be seen, the EU proposal is an amalgam of the different preceding measures. For this reason, it is hard to say whether it is 'stricter', or 'more lenient'. Everything depends on the particular aspect that is being stressed.

The most interesting question concerns the relation of the forthcoming EU regime to laws previously adopted by the Member States. One would normally expect that a European regulation would supersede any measures taken by the Member States, and that with its entry into force, the French, German and British reforms would no longer apply. However, the proposal contains a sort of 'grandfather clause' that allows any acts adopted before its publication - that is before 29 January 2014 - to stay in place, provided that certain criteria are fulfilled. ${ }^{73}$ It is apparent from these criteria that their purpose is to allow the UK to keep its legislation. It will probably not fit the French and the German acts because the latter do not require that transactions between the trading entity and the deposit-taking institutions are made only on arms' length. Even more striking than this differentiation is the fact that any other national measures that comply with the requisite criteria and introduced after the 29 January 2014 deadline will be overwritten by the Regulation. This raises important questions of Member States' equality because there will be no plausible reason for treating legislators differently other than when they enacted legislation. One will have to wait and see whether the Council and the European Parliament will accept the arbitrary deadline drawn by the proposal.

From a drafting point of view, the EU proposal faces the same challenges as the national laws analysed so far because it is essentially a combination of them all. Worse still, it even leads to an additional problem. By placing the decision over structural reform into the hands of the supervisory authority, it creates the necessity to review the activities of the banks on a continuous basis and to define when separation shall be ordained. To this end, the proposal suggests extensive metrics, ${ }^{74}$ the details of which remain to be defined by a delegated act of the Commission. ${ }^{75}$ The whole procedure seems complex and is hard to reconcile with the Commission's general ambition to adopt simpler legislation.

\footnotetext{
${ }^{69}$ Art. $14 \mathrm{COM}(2014), 43$ final.

${ }^{70}$ Art. 13(7) $\operatorname{COM}(2014), 43$ final.

${ }^{71}$ Art. 13(8) $\operatorname{COM}(2014), 43$ final.

72 Art. 13(10) COM(2014), 43 final.

${ }^{73}$ Art. 21 COM(2014), 43 final.

${ }^{74}$ Art. 9(2)(a)-(h) $\operatorname{COM}(2014), 43$ final.

75 Art. 10(5) COM(2014), 43 final.
} 


\section{IMPACT OF LEGAL FRAGMENTATION ON GLOBAL BANKING}

The foregoing analysis has shown the existence of a plethora of different structural measures throughout various jurisdictions. None of the measures analysed exactly matches the measures adopted by another state. Even the Commission proposal will not lead to a completely harmonious regime in the EU. This picture must be amplified even more by other states that may consider adopting structural reforms as well. For instance, legislative reform has recently been adopted in Belgium, even though it may come too late once the Commission's proposal for an EU Regulation is adopted. 76

Once these multiple measures will have entered into force, the banking business will be split into different national models. No one national bank will be like another anymore. A ring-fenced entity under UK law, for instance, is a very different animal from a US bank or a French or German deposit-taking institution. Even though they may all manage retail bank accounts, their ability to offer other services, their right to engage in trading activities, and their relation to other members within their own banking group are quite different. It is of course true that different banking models have always existed, such as universal and investment banks, for example. The novelty is, however, that the banks thus far had a choice between these models, whereas they are now prescribed by national law.

There are good reasons to wonder about the effect of this legal fragmentation on the global financial system. What shall be asked here is not so much which of the measures is likely to achieve the economic goal of making deposits safer, a question on which economists have expressed different opinions. ${ }^{77}$ The focus is rather on their combined effect on the global banking market.

To understand the implications of legal fragmentation, one must first clarify what the respective scopes of the structural measures are. They apply to institutions that are authorised and supervised as banks in the state that has adopted the respective legislation. ${ }^{78}$ Typically, these banks are required to be incorporated under the law of this state and maintain their seat there. ${ }^{79}$ It follows that each state applies the reform legislation to 'its' banks. We are thus facing a sort of renationalisation of banking.

\footnotetext{
76 Art. 117-133 de la Loi relative au statut et au contrôle des établissements de crédit du 25 avril 2014, Moniteur belge du 7 mai 2014, p. 36794.

77 See, e.g., José Viñals, Ceyla Pazarbasioglu, Jay Surti, Aditya Narain, Michaela Erbenova, and Julian Chow, Creating a Safer Financial System: Will the Volcker, Vickers, and Liikanen Structural Measures Help?, IMF Discussion Note, SDN/13/4, 14 May 2013, available at https://www.imf.org/external/pubs/ft/sdn/2013/sdn1304.pdf (last visited 19.3.2014); Adrian BlundellWignall, Paul Atkinson and Caroline Roulet, Bank business models and the separation issue, 2013/2 OECD Journal: Financial Market Trends p. 1; Leonardo Gambacorta and Adrian van Rixtel, Structural bank regulation initiatives: approaches and implications, BIS Working Paper No 412, April 2013, available at http://www.bis.org/publ/work412.pdf (last visited 19.3.2014).

${ }^{78}$ See 12 U.S.C. \ 1851 ('banking entity'); Art. L511-41-I Code monétaire et financier ('etablissement de crédit et sociétés de financement'); \$3(2) 1 Kreditwesengesetz ('CRR-Kreditinstitute').

${ }^{79}$ See e.g. in Germany $₫ 33(1) 1$ No. 6 Kreditwesengesetz.
} 
At the same time, it is important to bear in mind that banks do not only offer their services in their respective countries of origin. Many of them are global players, acting on a worldwide level. The structural reform measures adopted by their country of origin affect them when they offer their services abroad. They automatically extend to any of their foreign branches operating in other countries. The EU proposal explicitly stresses this extraterritorial ambition, ${ }^{80}$ but in reality, such a statement is merely declaratory because a branch is, legally speaking, nothing else than the bank itself. Some legislators go even further and subject their bank's subsidiaries in other countries to these prohibitions. ${ }^{81}$ Nevertheless, the result is that the acts have broad extraterritorial effects.

Financial institutions will thus be put into regulatory straightjackets by their home states. These national straightjackets will govern their activities in other states. It is likely that this combination between nationalism and extraterritoriality will have far-reaching repercussions.

The first of them concerns competition. In the global banking market, there will be a number of banks or banking groups that may receive deposits and engage in speculative activities, while others may not. The result is that some of them will recoup bigger returns, although they may at the same time become more risky. There is simply no level playing field between these fundamentally different actors. Each of them will have a very different background. In the future, this may lead to the risk of encouraging regulatory arbitrage. When looking for a country to incorporate a bank, the bank's founders may be influenced first by the structural requirements that respective laws provide. To counter these effects, the European Commission suggests extending the prospective EU regime to the bank branches of third countries. ${ }^{82}$ But this would only provoke insoluble clashes with other legal systems and further increase restrictions within the EU market. The Commission has already backtracked by providing an exception that applies where the legal framework in the foreign bank's country of origin is deemed 'equivalent' to that in the EU. 83

The second effect concerns the efforts to establish a worldwide uniform regulation of finance. As a result of the structural reforms, it will be much more difficult to treat credit institutions established in different nations consistently. Some of them will no longer be bailed out, but will instead be left high and dry in cases of insolvency, while others may still enjoy some support by their parent institution or by their state of origin. This makes it more difficult to draft uniform standards to safeguard financial stability around the globe. So far, banks are basically subject to similar capital requirements drawn up by the Basle Committee on Banking Supervision (Basle I-III). But what good are they in ensuring global financial stability if the banks that are subject to these rules are very different in

\footnotetext{
${ }^{80}$ See, e.g., Art. 3(1)(a) $\operatorname{COM}(2014) 120$ final.

${ }^{81}$ See Art. L511-41-I Code monétaire et financier.

82 Art. 3(1)(b)(iii) $\operatorname{COM(2014)~} 120$ final and p. 7 there.

83 Art. 4(1)(a) COM(2014) 120 final.
} 
nature? Should a bank that is allowed to engage in proprietary trading not be subject to much stricter rules than a bank that is not? Similarly, resolution requirements that have been suggested by the $\mathrm{FSB}^{84}$ may not be suitable for all types of credit institutions. It is much more complicated to rescue a deposit-taking bank that is a member of a French or German banking group, for instance, than it is to save a British ring-fenced body.

The third effect will be on the banks' clients. They may be confused as to the reliability and robustness of the banks to which they entrust their deposits. Banks may offer their services anywhere in the world. Some legislation specifically requires a separate name for deposit-taking institutions and trading entities, while others do not. Customers may be enticed to put their money in a foreign bank that offers retail services without being aware of its peculiar design, or its involvement with other members of its group. It will be quite difficult to explain to laymen the different banking structures that exist under the different national laws, and the respective repercussions that impact the safety of their deposits.

This is not to say that we would be better off with a global, uniform reform. On the contrary, some experimentation with the appropriate banking structures is welcome. Nobody knows for certain which regime works best. Thus, unless different structures are tested out, we may possibly never reach a sound conclusion. Moreover, if the structural regime was to be globally uniform, any shortcomings would affect all banks across the world, and not just those incorporated and supervised in one country. As a result, the global system would become much more vulnerable. It is, of course, also true that each state has the right to decide how it wants to structure its banks so that they pose no risk for taxpayers and depositors.

However, one must also bear in mind that with today's interconnected markets, the failure of one credit institution has the potential to trigger a worldwide financial crisis. Even if one national legislator makes his bank particularly safe, he cannot prevent foreign banks from becoming insolvent. When it comes to financial stability, states are dependent on each other. There is thus no point in each of them working on structural reform independently. Some coordination is necessary. At a minimum, global soft law regulators, such as the BCBS or the FSB, should assess the potential repercussions of different national banking structures in their work. It would be even better to see them give guidelines to help smooth out the greatest divergences between national banking structures.

\footnotetext{
${ }^{84}$ Financial Stability Board, Key Attributes of Effective Resolution Regimes for Financial Institutions, October 2011, available at https://www.financialstabilityboard.org/publications/r 111104cc.pdf (last visited 20.3.2014).
} 